\title{
A Case of Chordoma Invading Multiple Neuroaxial Bones: Report of Ten Years Follow Up
}

\author{
Multisentrik Kordoma: 10 YallıkTakip
}

\author{
Ahmet Levent AYDIN ${ }^{1}$, Mehdi SASANI ${ }^{2}$, Tunc OKTENOGLU², İhsan SOLAROGLU ${ }^{3}$, Ali Fahir OZER ${ }^{3}$ \\ ${ }^{1}$ Istanbul Physical Therapy and Rehabilitation Hospital, Department of Neurosurgery, Istanbul, Turkey \\ ${ }^{2}$ American Hospital, Department of Neurosurgery, Istanbul, Turkey \\ ${ }^{3}$ Koc University, Faculty of Medicine, Department of Neurosurgery, Istanbul, Turkey
}

Corresponding Author: Mehdi SASANI / E-mail: sasanim@gmail.com

\begin{abstract}
AIM: Chordoma is a rare, slow-growing primary malignant tumor of the axial skeleton, arising from the embryonic cells of primitive notochord. Chordomas may arise at different sites of the vertebral column simultaneously or more probably they may metastasise along the neural axis insidiously. Recurrence despite radical surgery and following adjuvant therapy is possible.

MATERIAL and METHODS: A 46-year-old female patient presented weakness and numbness of the lower extremities. She was operated for clivus chordoma five years ago at another institute.

RESULTS: First the patient underwent surgery for resection of the tumor at the cervical region. a second surgery was performed to resect tumor on the foramen magnum and at the $\mathrm{C} 1$ level. Histologic examination of the removed vertebra confirmed the diagnosis of chordoma involving the vertebral body. Radiotherapy was administered after the second surgery. Follow-up neurological and radiological examinations revealed no abnormal neurological symptoms 2,5 years after second surgery. There were no distant organ metastases.

CONCLUSION: A patient with diagnosed chordoma of the spine must be investigated with MRI of other regions of the neuraxis to exclude second or even third source of chordoma metastases. In metastatic chordoma cases, radical or gross total resection should be performed for each lesion but if complete surgical resections are impossible, preoperative or postoperative radiation therapy should be planned to improve life expectancy.
\end{abstract}

KEYWORDS: Chordoma, Cervical tumor, Thoracal tumor, Spinal tumor, Metastasis

öz

AMAÇ: Kordoma, omurganın ender rastlanan, yavaş ilerleyen malign karakterli bir tümörüdür. Primitif notokordun embryo hücrelerinden köken alır. Omurganın farklı bölgelerinde, birbirinden bağımsız kordoma odakları eş zamanlı olarak gelişmeye başlayabilir. Fakat daha sıklıkla, birinci tümör odağından kaynaklanan metastatik kordoma lezyonları tüm nöral aks boyunca yayılabilir. Radikal cerrahiye ve ek onkolojik tedaviye rağmen rekürens sık görülür.

YÖNTEM ve GEREÇLER: Bu sunumda tartışılan 46 yaşındaki kadın hasta, bacaklarında kuvvet ve his kaybı şikayetiyle kliniğimize başvurmuştur. Hasta, beş yıl önce, ayrı bir merkezde klivus kordoması tanısıyla opere edilmiştir.

BULGULAR: Hasta öncelikle servikal bölgedeki tümör için opere edilmiştir. İkinci seansta foramen magnum ve C1 seviyesindeki tümör çıkarılmıştır. Patolojik inceleme sonucunda, omurga cismini tutan kordoma lezyonu tanısı konmuştur. İkinci cerrahi seansından sonra hasta radyoterapiye yönlendirilmiştir. Bu tedaviden ikibuçuk yıl sonra yapılan değerlendirmede, hastanın nörolojik muayenesinde progresyon gözlenmemiştir.

SONUÇ: Omurganın herhangi bir lokalizasyonunda kordoma tanısı konulan bir hastada, tüm spinal bölge manyetik rezonans görüntüleme (MRG) tetkiki ile incelenmelidir. Bu hastalarda birden fazla kordoma odağına rastlanabilir. Birden fazla odak tespit edilmesi durumunda, her ayrı tümör odağı için rezeksiyon planlanmalıdır. Total rezeksiyonun mümkün olmaması durumunda, yaşam süresini uzatmak için operasyon öncesi ve sonrası dönemlerde radyoterapi uygulanmalıdır.

ANAHTAR SÖZCÜKLER: Kordoma, Servikal tümor, Torakal tümor, Spinal tümor, Metastaz

\section{INTRODUCTION}

Chordoma is a rare, slow growing primary malignant tumor of the axial skeleton, arising from the embryonic cells of the primitive notochord. The notochord is the cell line from which the base of cranium and the vertebra develop. Chordomas show a dual epithelial-mesenchymal differentiation (4).
It is a tumor of the fifth and sixth decades. Skull-base presentations affect a younger age, and may even occur in children and adolescents (4). Chordomas afflict men as twice as women (male-to-female ratio 1.7-3:1). For sacral chordomas, male predominance is $3: 1$. The majority of the tumors are seen at the sacrococcyceal area (50\%), followed by the basioccipital area $(35 \%)$. The remainder is distributed over the rest of the spine $(7,13)$. 
Chordomas have very low rate of metastasis but this is compensated by their local invasiveness and high local recurrence rate (7).

Different foci of chordomas may arise at different sites of the vertebral column simultaneously. Hereby, we presented a case with three different foci of chordomas along the neural axis. This case is probably a case of seeding metastasis of the clivus chordoma along the neural axis. We excluded the diagnosis of multicentric chordoma, as the onset of the different foci was at different times. Multicentric chordomas are especially very rare and, to our knowledge, only two cases of multicentric chordomas have been reported. Metastatic chordomas are more frequently seen $(2,10,14)$.

\section{CASE REPORT}

A 46-year-old female patient was referred to the emergency clinic with complaints of weakness and numbness of the lower extremities. These complaints had started 2 days before attending to the hospital after a minor trauma. She defined back pain at the dorsal region lasting for about one month.

In her past medical history, she was operated for clivus chordoma five years ago in a foreign country institute.

On physical examination, there was paravertebral muscle spasm at the level of 3rd dorsal vertebra. Her neurological examination revealed moderate paraparesia (muscle strength $3 / 5$ bilaterally) at the lower extremities, deep tendon reflex hyperactivity, and hypoesthesia below the level of T3.

Thoracal magnetic resonance imaging (MRI) examination revealed diffuse signal abnormality at the level of T3 with decreased signal on T1, and increased signal on $\mathrm{T} 2$ sequences. The lesion was expanding to and compressing the spinal cord at the same level (Figure 1). Laboratory tests, including hematology, chemistry group, carcinoembryogenic antigen, and serum protein electrophoresis, were all within normal limits. The patient was then evaluated with abdominopelvic computed tomography (CT), chest $\mathrm{CT}$, whole body bone scan, and positron emission tomography (18-FGD) whole body scan for possibility of metastasis. There was no metastatic evidence in other regions.

\section{First Surgical Procedure}

A gross total resection of the involved vertebra was performed through staged posterior and anterior approaches. In the first stage, by posterior approach, T3 total laminectomy, epidural tumor excision, T2-T4-T5 fixation with transpedicular screw and rod system were performed. In the second stage, T3 tumor was excised atfer thoracotomy and an expandable cage was used for fixation (Figure 2A,B).

Histologic examination of the removed vertebra confirmed the diagnosis of chordoma involving the vertebral body. There were cells with clear cytoplasm that infiltrated the bony trabeculae. These "physiliphorous" cells had slight cytologic atypia (Figure 3).

After the operation, her neurological condition was as preoperatively and she was discharged from the hospital 10 days later. Physical therapy was performed for 6 months. Follow up neurological examination on 6,9 and 12 months revealed no neurological symptoms.

The patient was referred to our hospital with a diagnosis of upper cervical tumor 2.5 years after the thoracal cordoma operation. She had been complaining of severe neck pain, dysesthesia of both arms and headache for the last one

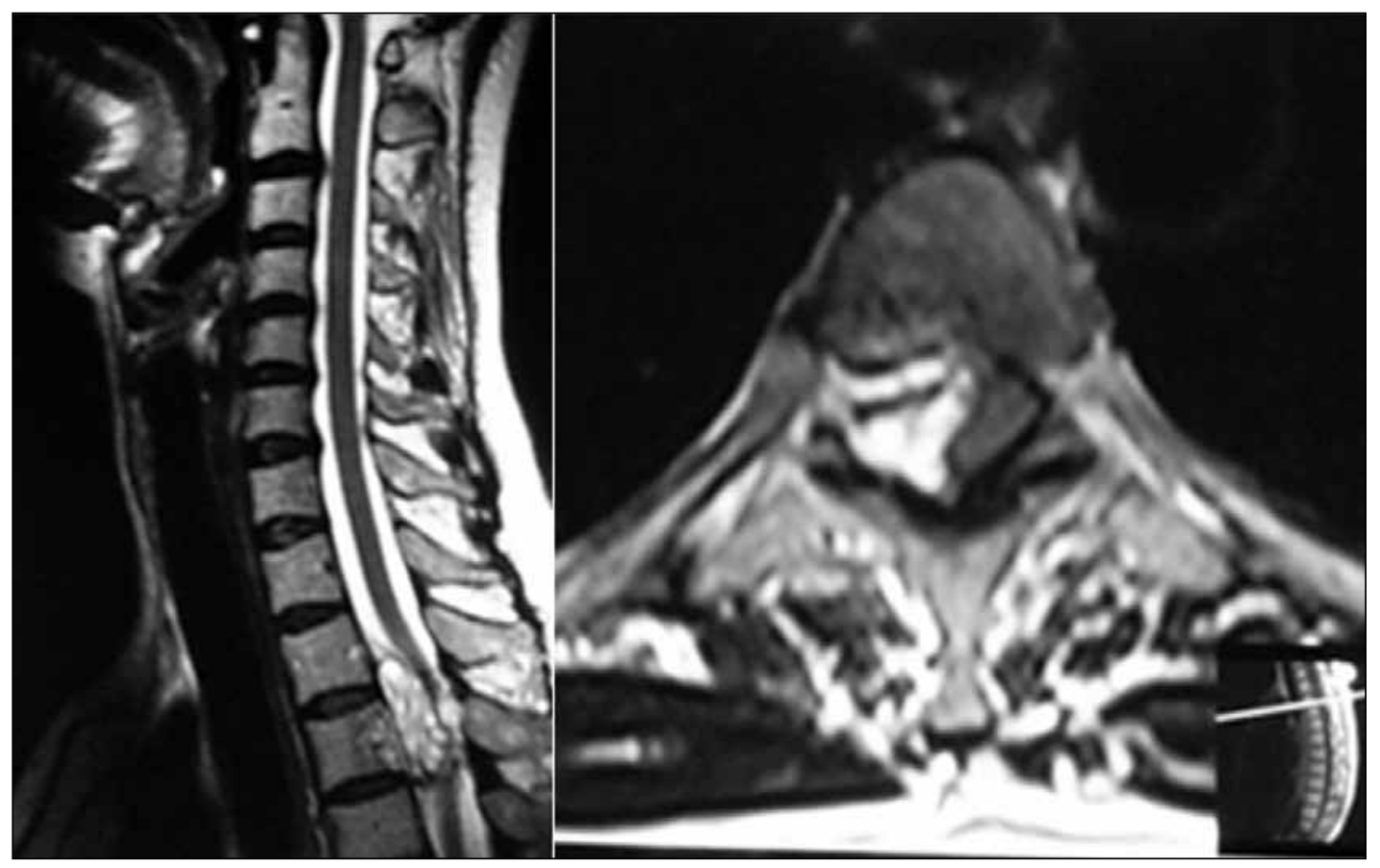

Figure 1: A thoracal MR scan (Axial and sagittal plans) showed a intra spinal canal mass on L2, L3 levels. 


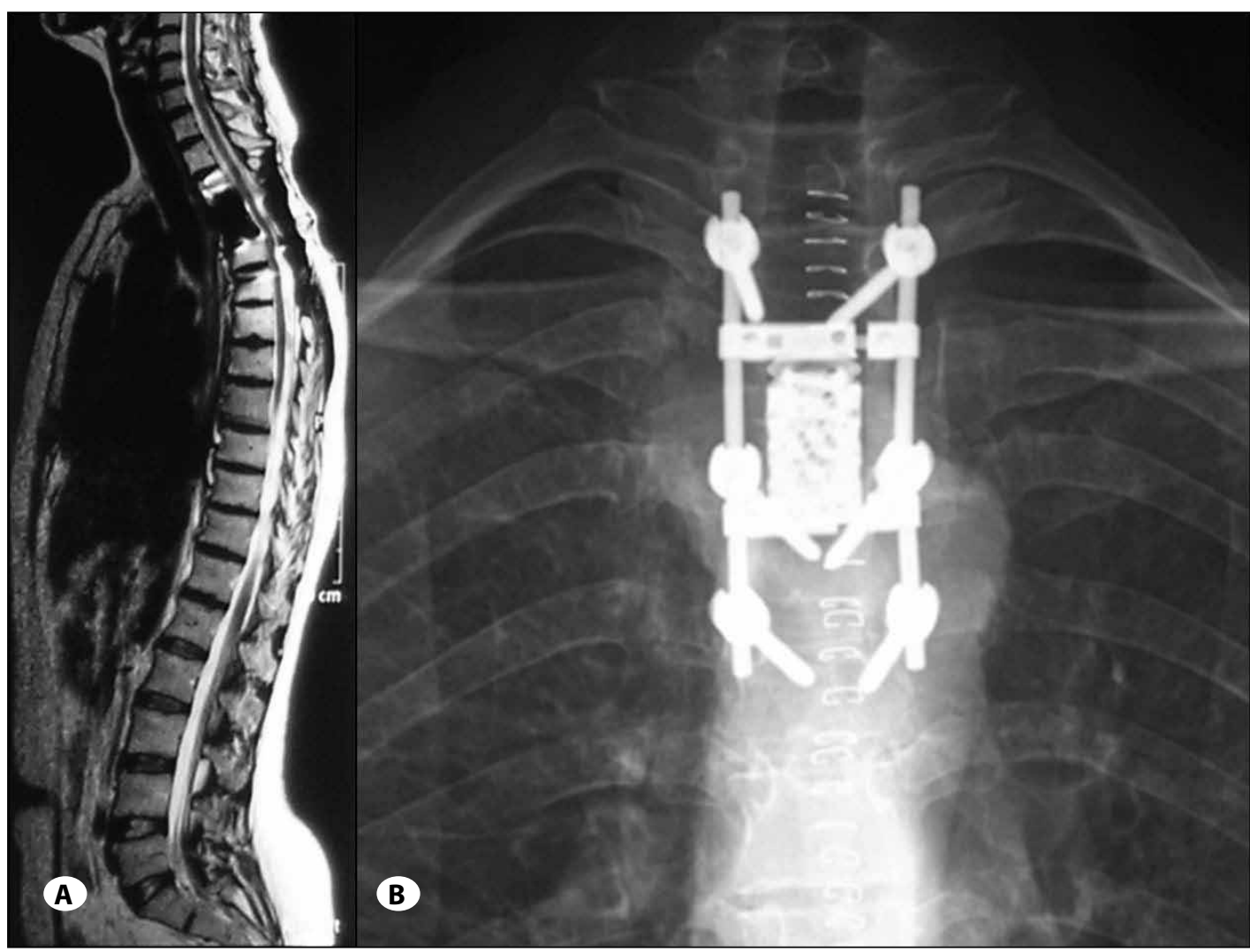

Figure 2:

Postoperative radiologic demonstration: A) Anterior posterior thoracic plan X-ray, B) sagittal $T 2$ weighted MR scan. month. The neck pain was located in the posterior midline, and it radiated to the shoulders bilaterally. There was no weakness of her arms.

Her cervical MRI scan showed diffuse signal abnormality within the $C 1$ and $C 2$ vertebral bodies, with decreased signal on T1 and increased signal on T2 sequences and paravertebral tumoral lesion. The tumor was compressing the spinal cord (Figure 4).

\section{Second Surgical Procedure}

The patient was positioned in prone position with the head fixed with three-pin frame holder. By the posterior approach, C1 and C2 laminectomy, excision of the intradural component of the tumor, dura repairing and dissection of of the tumor tissue from the vertebra and excision of the invaded paravertebral muscle tissue were performed.

Histologic examination of the tumor tissue revealed chordoma just as first histologic examination.

She was discharged 5 days postoperatively and referred to the radiation oncology department for radiotherapy. Followup neurological and radiological examinations revealed no abnormal neurological symptoms 2,5 years after the second surgery.

\section{DISCUSSION}

Chordomas are traditionally been considered slow growing, locally invasive neoplasms constituting between 1 and 4 percent of malignant bone tumors in large series. It has an incidence of $0.1 / 100000 / y e a r(13,15)$. Although they are tumors of bone, they have also been reported at extraosseous sites, predominantly in the parapharyngeal area. They may be multicentric or arise as a second neoplasm. A few such cases have been reported in the literature. (12).

They arise from embryonic notochord remnants and in most cases occur in the sacrococcygeal and spheno-occipital regions. Sacrococcygeal chordomas often occur in patients between the ages of 50 and 70. Spheno-occipital region chordomas usually present a decade earlier.

More than $50 \%$ of these lesions are located in the sacrococcygeal region, $35 \%$ are located in the clival and cervical area, and the rest are spread throughout the vertebral column, with a distribution of $61.1 \%$ in the lumbar, $11 \%$ in the thoracic and $27.8 \%$ in the cervical spine. The first lesion of our case was in the clivus, the second lesion was in thoracic vertebral region, and the third lesion was in the cervical vertebral region.

The rarity of the thoracic chordomas deserves a point of interest. We found 120 reports in pubmed for thoracic chordoma. The initial symptoms of thoracic chordoma are subtle and nonspecific. Usually, symptoms are seen with spinal cord compression or thoracic viscera compression $(1,9,11,15)$. The second tumor of our case was at the thoracal region, T3 level. 
In the radiological diagnosis, bone scan shows no uptake for both Tc-99m and gallium tracers.

CT scan shows the extent of bone destruction. MRI is the study of choice for chordoma. It shows a lesion in high contrast to the adjacent soft tissues on T2 weighted images.

In the differential diagnosis, neural tumors such as schwannomas or neurofibromas posterior mediastinal chondrosarcomas must be considered. It is difficult to differentiate these tumors radiographically.

Histologically, chordoma tumor cells are typical. They display vesicular nuclei and have abundant vacuolated, soap bubblelike cytoplasm (physiliphorous cells). They are arranged in nests, cords, or sheets within a myxoid stroma (5) (Figure 5).

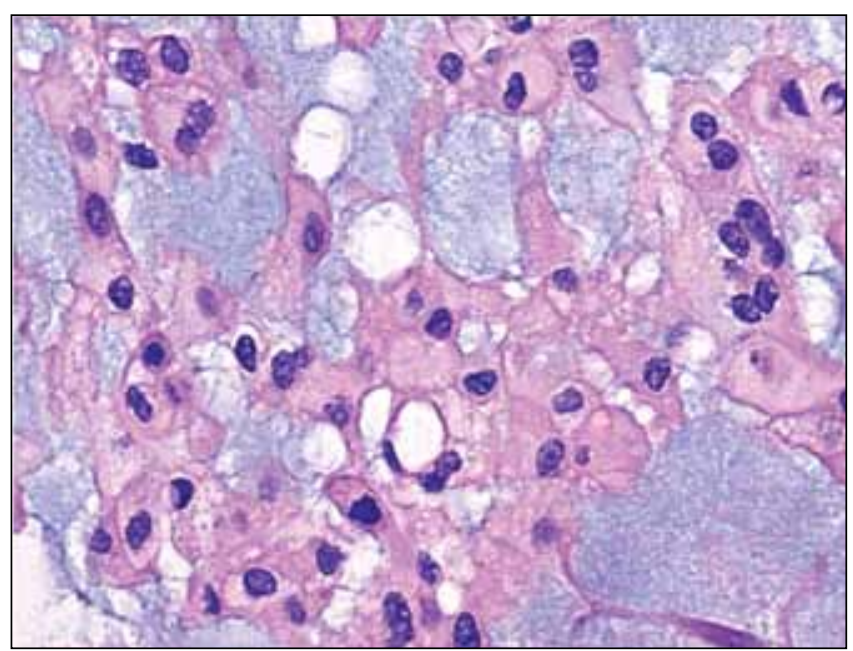

Figure 3: Physaliferous cells are characteristic of chordoma.
Chordomas are locally invasive, have high recurrence rate, and have potential for metastasis. They show metastasis to the lymph nodes, lung, liver, brain, or bone, and the reported incidence of metastasis varies from $5 \%$ to $43 \%$ (10). To detect the metastasis, whole body bone scan, chest $\mathrm{CT}$, abdominopelvic CT, PET scan should be done. In this case, the patient did not show any evidence of metastasis apart from the neural axis from these studies.

Besides, chordomas have a well-known tendency to recur locally. En bloc removal is difficult in most cases because of the anatomic constraints of surgical accessibility and the proximity of neural tissue and other intrathoracic vital organs. En bloc resection is feasible in only $40 \%$ of lesions, and it is attended by significant mortality and morbidity (7). In our case, gross total resection was performed for the thoracic metastasis.

Intralesional excision is associated with high recurrence rates $(6,10)$. Most of the cases become symptomatic when the lesion becomes very large, rendering complete excision impossible.

The high rate of local recurrence and local invasiveness explain the low distant metastasis rate (7).

Between 5 and 20 percent of chordomas may behave as highgrade sarcomas at initial presentation, while 10 to 30 percent metastasize to multiple sites following attempts at resection. The sites of metastasis vary, and include soft tissues, lymph nodes, lung, bone, liver and other intraabdominal viscera (13).

In the presented case, the patient presented at the hospital because of neurological signs and symptoms, so diagnosis

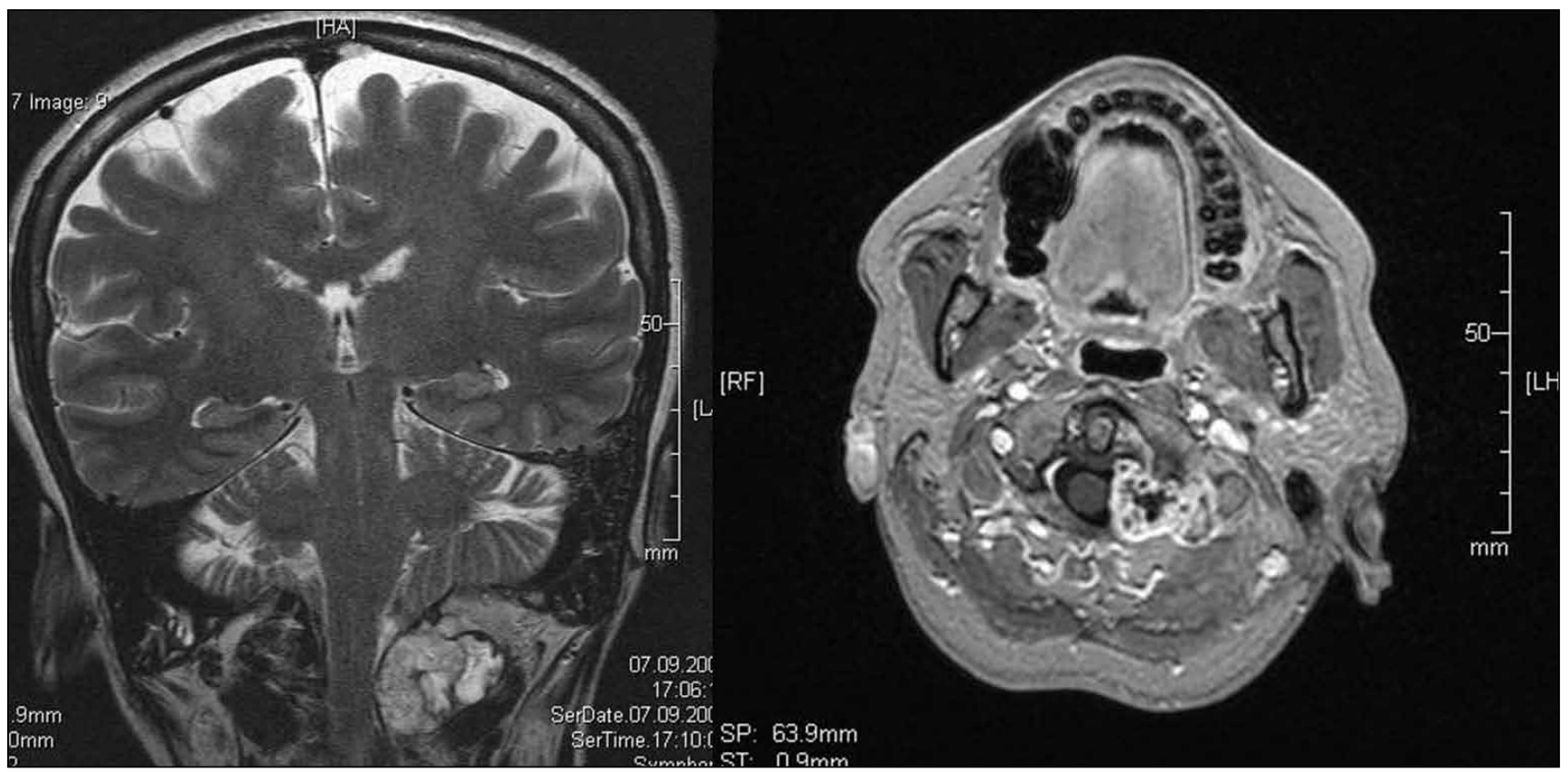

Figure 4: A cervical MRI (coronal and axial) scans showed diffuse signal abnormality within the C1 and C2 vertebral bodies, with decreased signal on T1 and increased signal on T2 sequences and paravertebral tumoral lesion. 


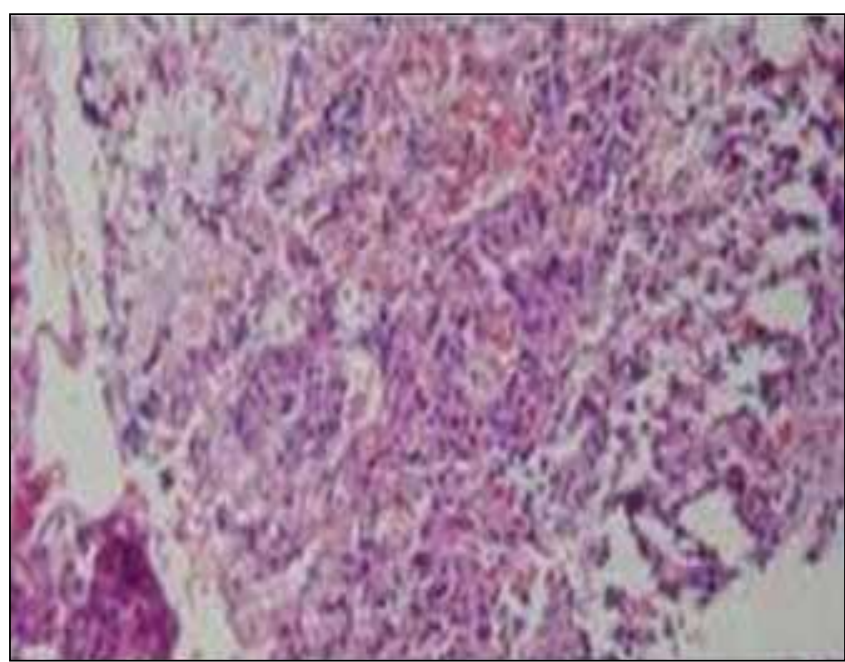

Figure 5: Pathologic specimen of the chordoma invading bone.

and surgical intervention was performed before distant metastases were seen.

The treatment of choice for chordoma is surgical resection. The margins of initial resection predict future local recurrence, tumor spillage and ultimate outcomes. About 85\% 5 year overall survival and $60 \%$ local recurrence free survival are reported by the authors after complete resection. Local recurrence is a poor prognostic sign. In subtotal resection, long-term local control rates are reported to be less than $50 \%$ even if postoperative radiotherapy is administered (16). Our patient did not have local recurrence but she had neuraxial distant seeding metastasis 5 years after the first operation, 2.5 years after the second operation in spite of postoperative radiotherapy (as discussed later, we could not differentiate seeding metastasis from multicentric tumor).

Radiation therapy is frequently used as postoperative treatment. Unfortunately, chordomas are considered radioresistant when conventional radiotherapy is used. CyberKnife stereotactic radiosurgery, external beam radiotherapy, proton beam radiotherapy and gamma knife radiotherapy have all been shown to be effective in the preoperative or postoperative treatment of chordomas (7). The disease-free survival time for chordomas treated with surgery alone was 4.1 years compared with 6.6 years for those treated with surgery combined with appropriate radiation therapy (8).

If tumor spillage is expected during surgical removal, preoperative irradiation is indicated.

Conventional chemotherapy does not play role in chordoma cure and reports of tumor responses to regimens including anthracyclines, cisplatin and alkylating agents have been only anecdotal. Only imatinib mesylate has been found to have antitumor activity in patients with chordomas in a small study $(3,4,15)$. Postoperative chemotherapy was not used in the presented case.
Our case involved three discrete chordomas as a result of seeding metastasis in the clival, thoracic and cervical regions, presenting at discrete periods. At each surgical intervention, the tumor was gross totally excised with wide margins, including the paravertebral muscle tissue and postoperative radiation therapy was administered. Pathological examination of the tumor showed tumor-free margins of the excised tissue. Although chordomas have a well-known tendency to recur locally and the recurrence rate seems to be related to incomplete resection, no local recurrence was seen in our case.

The presented case is probably a seeding metastatic case of clivus chordoma. This case is different from multicentric chordoma because the tumor foci appeared at different times, and not at the first onset.

In conclusion, chordomas are slow-growing tumors that tend to recur locally and metastasize. A patient with diagnosed chordoma of the spine must be investigated for other regions of the neuraxis with MRI to exclude a second or even third source of primary chordoma. Although chordomas are slowgrowing tumors that tend to recur locally and metastasize, they rarely occur multicentrically. This case could be regarded as a chordoma involving multiple neuraxial bones, as a result of seeding metastasis. In both multicentric or neuraxial metastatic chordoma cases, radical resection should be performed for each lesion at the initial diagnosis. If complete surgical resections are infeasible or impossible, preoperative or postoperative radiation therapy should be planned for the highest possibility of successful treatment. Thus, the life expectancy of the patient could be more than 10 years.

\section{REFERENCES}

1. Ahrendt MN, Wesselhoeft CW: Chordoma presenting as a posterior mediastinal mass in a pediatric patient. J Pediatr Surg 27:1515-1518, 1992

2. Anderson WB, Meyers $\mathrm{HI}$ : Multicentric chordoma. Report of a case. Cancer 21:126-128, 1968

3. Casali PG, Messina A, Stacchiotti S, Tamborini E, Crippa F, Gronchi A, Orlandi R, Ripamonti C, Spreafico C, Bertieri R, Bertulli R, Colecchia M, Fumagalli E, Greco A, Grosso F, Olmi P, Pierotti MA, Pilotti S: Imatinib mesylate in chordoma. Cancer 101:2086-2097, 2004

4. Casali PG, Stacchiotti S, Sangalli C: Chordoma. Current opinion in oncology 19:367-370, 2007

5. Crapanzano JP, Ali SZ, Ginsberg MS, Zakowski MF: Chordoma: A cytologic study with histologic and radiologic correlation. Cancer 93:40-51, 2001

6. Currier BL, Papagelopoulos PJ, Krauss WE: Total en bloc spondylectomy of C5 vertebra for chordoma. Spine 32: 294-299, 2007

7. Henderson Fraser C, McCool Kyle, Seigle Juliet, Jean Walter, Harter William, Gangon Gregory J: Treatment of chordomas with cyberknife: Georgetown University experience and treatment recommendations. Neurosurgery 64:44-53, 2009 
8. Hitchon PW, Bilsky MH, Ebersold MJ: Primary bony spinal lesions. In: Benzel EC (ed), Spine Surgery Techniques, Complications, Avoidance, and Management. Vol: 1. Philadelphia: Elsevier, Churchill Livingstone, 2005:992-1014

9. Huang SM, Chen CC, Chiu PC, Lai PH, Ho JT, Tseng HH: Unusual presentation of posterior mediastinal chordoma in a 2-yearold boy. J Pediatr Hematol Oncol 25:743-746, 2003

10. Lim JJ, Kim SH, Cho KH, Yoon do H, Kim SH: Chordomas involving multiple neuraxial bones. J Korean Neurosurg Soc 45:35-38, 2009

11. Murphy JM, Wallis F, Toland J, Toner M, Wilson GF: CT and MRI appearances of a thoracic chordoma. Eur Radiol 8:1677-1679, 1998

12. Shahzada A, Hideyuki M, Wolfgang M: Clivus Chordoma: Is it enough to image the primary site? Skull base: An Interdisciplinary Approach 20:111-113, 2010
13. Sundearesan N, Krol G, Sen C: Spinal chordomas. In: Wilkins $\mathrm{RH}$, Rengachary SS (eds), Neurosurgery. Vol. 2. McGraw-Hill, 1996:1815-1825

14. Tang TT, Dunn DK, Hodach AE, Harrist TJ, Mihm MC Jr: Subcutaneous and skeletal chordomoid nodules in an infant. Am J Dermatopathol 3:303-310, 1981

15. Wang TJ, Shu SH, Lin CW, Chen LF, Lin TC, Chang Chien HS, Chan KY, Lee MY, Wang YA, Huang CJ, Liu CC: Thoracic chordoma: An unusual presentation of the spinal tumor. Am J Med Sci 335:239-241, 2008

16. Wu AJ, Bilsky MH, Edgar MA: Near complete pathological response of chordoma to high dose single-fraction radiotherapy: Case report. Neurosurgery 64:389-390, 2009 